\title{
Geosynthetic Clay Liner Permeated with Acid Rock Drainage: The Role of Iron in Arsenic Immobilization
}

\author{
Angelica NAKA ${ }^{1 *} \cdot$ Takeshi KATSUMI $^{2} \cdot$ Takehiro OHTA $^{3} \cdot$ Giancarlo FLORES $^{4} \cdot$ \\ Toru INUI ${ }^{5} \cdot$ Atsushi TAKAI $^{6}$
}

\begin{abstract}
Geosynthetic clay liners (GCLs) have the potential to immobilize cations present in solution. Due to this, GCLs have been considered suitable materials not only in landfill bottom liners, but also in rock containments with the potential of acid rock drainage (ARD) generation. However, the bentonite inside GCLs does not have affinity towards anions such as arsenic, which is one of the toxic components present in ARDs. Based on the authors' previous research on swelling, sorption, and hydraulic conductivity of GCL against ARD, thorough discussion on the role of Fe in As immobilization was done in this paper. Swelling test showed that the presence of metals, especially a high concentration of $\mathrm{Fe}(4,500 \mathrm{mg} / \mathrm{L}$ approximately) due to its high concentration, negatively impact the swelling of bentonite by increasing the hydraulic conductivity value. The hydraulic conductivity remained low during the test duration but was one order of magnitude higher in the ARD permeation case $\left(5.0 \times 10^{-10} \mathrm{~m} / \mathrm{s}\right)$ than in the water permeation case $\left(1.4 \times 10^{-11} \mathrm{~m} / \mathrm{s}\right)$. Single metal sorption tests showed that Fe was sorbed by the bentonite while As was not. Sorption tests with different ARD dilutions showed that the increase of iron concentration positively impacts on As sorption. Considering that GCLs do not retain As, but Fe does, an additional Fe layer could be placed in the bottom liner system in order to immobilize it. However, if the ARD contains high Fe concentration, this additional layer would not be necessary as the Fe in solution will prevent As migration.
\end{abstract}

Keywords: Geosynthetic clay liner, Acid rock drainage, Hydraulic conductivity test, Swelling test, Sorption test

\section{INTRODUCTION}

The use and disposal of large amounts of materials coming from construction has become an important issue in Japan due to the growing interest in saving space in landfills and reducing the use of new natural resources ${ }^{1 \text {, }}$ 2), 3). Thus, reusing excavated materials has become a solution that reduces the amount of waste rock produced, as well of the consumption of new material. However, when rocks and soils are reused in geotechnical applications, the potential for pollution or natural contamination should be considered. In Japan, particularly, several types of metals such as $\mathrm{As}$ and $\mathrm{Pb}$ are present in a higher concentration compared to the average global level. Moreover, in mountainous areas of Japan, there are several rock formations which contain pyrite $\left(\mathrm{FeS}_{2}\right)$ and other minerals that may contain high amount of $\mathrm{As}$ and $\mathrm{Pb}$. Therefore, acid rock drainage (ARD) generated by the decomposition of sulfides with subsequent $\mathrm{As}, \mathrm{Pb}$ and other heavy metal leaching becomes a critical issue ${ }^{4), 5)}$. ARD is produced when sulfide minerals such as $\mathrm{FeS}_{2}, \mathrm{Cu}_{2} \mathrm{~S}, \mathrm{PbS}, \mathrm{ZnS}, \mathrm{CuFeS}_{2}$, or FeAsS are oxidized in the presence of oxygen and percolating water. Although this phenomenon occurs naturally, mining and excavation accelerate the generation of ARD by increasing the quantity of sulfides exposed. Because sulfides are only stable under strongly reducing conditions, exposing them to oxidizing conditions will destabilize these rocks and oxidation occurs through a variety of mechanisms ${ }^{6}$.

Heavy metals have negative effect on the environment and health; as natural processes do not degrade them, they remain in the ecosystem having a toxic effect on food chain through bioaccumulation. In order to prevent ARD surface and groundwater pollution, using an adsorption layer in rock containment facilities is considered a relatively new and cost-effective measure ${ }^{3)}$. This method places a layer of material in the bottom part of the waste rock containments that has adsorption capacity against heavy metals, such as geosynthetic clay liners (GCLs).

GCLs are bentonite-based liners that have large specific surface area, high metal adsorption capacity, and low hydraulic conductivity ${ }^{7,8), 9)}$.

Bentonite, specifically montmorillonite, can absorb heavy metals through two different $\mathrm{pH}$ dependent

\footnotetext{
${ }^{1}$ IGS Member, Graduate Student, Graduate School of Global Environmental Studies, Kyoto University, Japan

${ }^{2}$ IGS Member, Professor, Graduate School of Global Environmental Studies, Kyoto University, Japan

${ }^{3}$ JGS Member, Senior Researcher, Disaster Prevention Technology Division, Railway Technical Research Institute, Japan

${ }^{4}$ JGS Member, Lecturer, Graduate School of Engineering, Kyoto University, Japan

${ }^{5}$ IGS Member, Associate Professor, Graduate School of Global Environmental Studies, Kyoto University, Japan

${ }^{6}$ JGS Member, Assistant Professor, Graduate School of Global Environmental Studies, Kyoto University, Japan
} 
mechanisms: (1) Cation exchange in the interlayers and (2) formation of inner-sphere complexes through Si-Oand Al-O- groups at the clay particle edges ${ }^{10)}$. In acid conditions, the hydrogen ion competes with the heavy metals towards the superficial sites; additionally, most silanol and aluminol groups are less deprotonated which favours metal mobility ${ }^{10)}$. It was also found that the presence of ligands in solution influences the adsorption of heavy metals due to the formation of metal-ligand complexes. Lange et al. ${ }^{11)}$ have demonstrated that, in addition to montmorillonite clay's cation exchange capacity, minerals comprising less than $5 \%$ of the bentonite, such as goethite, gypsum and pyrite, play an important role in sequestering a range of metals, specifically $\mathrm{Ni}, \mathrm{Zn}$, and $\mathrm{Cu}$. Besides the crystalline initially present in the materials, those formed as a result of interaction between species present in the ARD (newly-precipitated minerals) can have a significant long-term impact on metal mobility ${ }^{11)}$.

In the author's previous research ${ }^{12)}$, 13) the barrier performance of geosynthetic clay liners (GCLs) against a pH 3 artificial ARD was investigated through swelling, hydraulic conductivity, and sorption tests. Based on these experimental results, a thorough discussion focused on $\mathrm{Fe}$ and As retention/release interactions, which seems to play an important role in As immobilization, is presented in this study. The bentonite inside GCLs has special affinity toward cations such as $\mathrm{Pb}, \mathrm{Mn}, \mathrm{Cd}$, etc., but not anion species, such as As, one of the toxic components present in ARDs. Thus, discussion was mainly focused on arsenic as it has a different behavior and sorption mechanism compared to the ARD's cations. Almost no migration of As was found due to its retention or precipitation mainly caused by the presence of Fe. This research differs from other studies in the type of ARD used (high metal concentrations, especially Fe), the longterm nature of the hydraulic conductivity experiments, and the study of the relationship between Fe and As.

\section{MATERIALS AND METHODS}

Experiments were conducted using a needle-punched GCL (Bentofix ${ }^{\circledR}$ NSP 4900) which contains powdered Na-bentonite sandwiched between woven and nonwoven geotextiles $\left(4,670 \mathrm{~g}\right.$ bentonite $/ \mathrm{m}^{2}$, at natural moisture content). It had $10 \%$ water content, a specific gravity of 2.85 and a smectite content of $80 \%$. An artificial ARD was prepared in the laboratory based upon the drainage composition of a $\mathrm{Pb}-\mathrm{Zn}-(\mathrm{Cu})$ deposit located in Cerro de Pasco, Peru ${ }^{14)}$, as shown in Table 1. This ARD was selected because it represents a very severe case of ARD in terms of metal concentration, much higher than the ones reported by other authors who studied acid rock drainage against $\mathrm{GCLs}^{8)}{ }^{8)}$. . The ARD was prepared by mixing guaranteed reagent (GR) grade $\mathrm{FeSO}_{4} \cdot 7 \mathrm{H}_{2} \mathrm{O}, \quad \mathrm{Al}_{2}\left(\mathrm{SO}_{4}\right)_{3} \cdot 16 \mathrm{H}_{2} \mathrm{O}, \quad \mathrm{CuSO}_{4} \cdot 5 \mathrm{H}_{2} \mathrm{O}$, $\mathrm{ZnSO}_{4} \cdot 7 \mathrm{H}_{2} \mathrm{O}, \mathrm{Na}_{2} \mathrm{HAsO}_{4} \cdot 7 \mathrm{H}_{2} \mathrm{O}, \mathrm{PbCl}_{2}, \mathrm{~K}_{2} \mathrm{SO}_{4}, \mathrm{Na}_{2} \mathrm{SO}_{4}$, $\mathrm{CaSO}_{4}$, and $\mathrm{MgSO}_{4}$. The $\mathrm{pH}$ was adjusted to 3, using
$\mathrm{H}_{2} \mathrm{SO}_{4(\mathrm{cc})}$ and the electrical conductivity (EC) was 1195 $\mathrm{mS} / \mathrm{m}$.

Table 1. Chemical composition of the artificial ARD

\begin{tabular}{cc}
\hline Metal & Concentration $(\mathrm{mg} / \mathrm{L})$ \\
\hline $\mathrm{Fe}$ & 4330.2 \\
$\mathrm{Cu}$ & 86.9 \\
$\mathrm{Zn}$ & 493.1 \\
$\mathrm{Al}$ & 259.2 \\
$\mathrm{As}$ & 49.1 \\
$\mathrm{~Pb}$ & 2.9 \\
$\mathrm{Na}$ & 413.9 \\
$\mathrm{~K}$ & 31.8 \\
$\mathrm{Mg}$ & 214.0 \\
$\mathrm{Ca}$ & 397.0 \\
\hline
\end{tabular}

A swelling test was conducted for different dilutions and bi-metal mixtures of the artificial ARD, according to the ASTM D 5890 "Standard Test Method for Swell Index of Clay Mineral Component of Geosynthetic Clay Liners". Two grams of dry powdered bentonite from the GCL was dusted into a $100 \mathrm{~mL}$ graduated cylinder filled with $90 \mathrm{~mL}$ of solution. The same solution was then used to fill the cylinder to $100 \mathrm{~mL}$. The cylinder was covered and allowed to stand undisturbed for 24 hours, with the volume level (in $\mathrm{mL}$ ) recorded.

Hydraulic conductivity tests on GCL were conducted according to the ASTM D 5084 "Standard Test Methods for Measurement of Hydraulic Conductivity of Saturated Porous Materials Using a Flexible Wall Permeameter" and ASTM D 7100 "Standard Test Method for Hydraulic Conductivity Compatibility Testing of Soils with Aqueous Solutions", using a falling headwater-constant tailwater system. A typical diagram of this system is presented in Figure 1. It consisted of a flexible wall permeameter, with a cell pressure of $30 \mathrm{kPa}$ and an average hydraulic gradient of 85-95, at a constant room temperature of $25^{\circ} \mathrm{C}$. The test specimen (GCL) was placed between filter papers, geotextiles, and plastic caps (cap and pedestal) with holes to connect the tubes, and confined by a latex membrane on the sides. The following variables were measured periodically: (1) the thickness of the GCL by a cathetometer; (2) the electrical conductivity (EC); (3) the $\mathrm{pH}$; (4) the effluent amount; and the (5) metal content by inductively coupled plasma spectroscopy method (ICP). Experiments were conducted using both distilled water and ARD as permeant solutions. All cases were monitored for 9 months. In the water permeation case, the GCL was directly permeated with water from the influent port. In the ARD permeation case, it was first prehydrated with the ARD solution before the long-term ARD permeation from the influent port. The prehydration was done by placing the GCL into a containment with the ARD solution for 7 days with a constant application of $30 \mathrm{kPa}$.

For the sorption test, different dilutions of ARD (from 2 to $100 \%$ ), and Fe and As single metal solutions (0 to $100 \mathrm{mmol} / \mathrm{L}$ approximately) were mixed with bentonite (obtained from the GCL) in a solid liquid ratio of $2 \mathrm{~g}$ 
bentonite/L solution for single metal and $20 \mathrm{~g}$ bentonite/L solution for ARD. In addition, different solidliquid ratios were tested over ARD solution (4 to $80 \mathrm{~g}$ bentonite/L). Experiments were conducted in $100 \mathrm{~mL}$ plastic bottles with caps, and the volume of the solution was fixed to $50 \mathrm{~mL}$. Once bentonite was added, the mixture was placed on a shaking table at $100 \mathrm{rpm}$ for 24 hours at $25^{\circ} \mathrm{C}$. Next, the mixture was centrifuged and filtered using a filter with a $0.45-\mu \mathrm{m}$ pore size. Metal concentration before and after the sorption tests were analyzed by ICP-MS (ICPS- 800 Shimadzu).

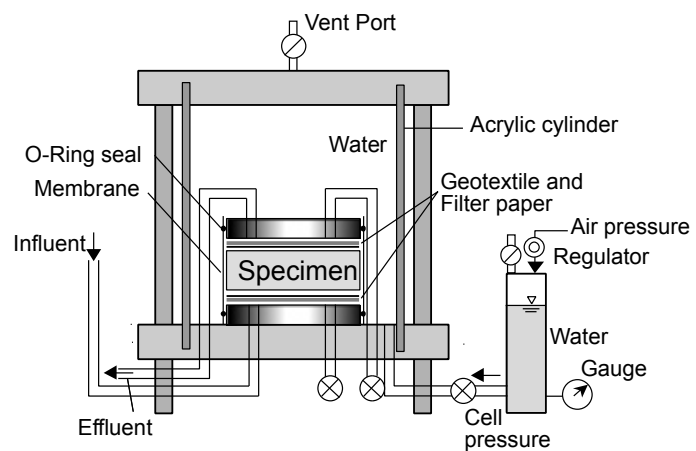

Figure 1. Schematic view of a flexible-wall permeameter. (Note: Closed valves $\otimes$ were kept closed through the test)

\section{RESULTS AND DISCUSSIONS}

\section{(1) Swelling test}

The results of the free swelling tests using different dilutions of the artificial ARD are shown in Figure 2. These indicate that a high metal concentration, corresponding to high ARD percentage in Figure 2, has a negative effect on the swell volume by making it lower. The swell index of $0 \%$ ARD (or distilled water adjusted to $\mathrm{pH} 3$ using $\mathrm{H}_{2} \mathrm{SO}_{4(\mathrm{cc})}$ ) was $32 \mathrm{~mL} / 2 \mathrm{~g}$ bentonite, while the swell index of $100 \%$ ARD was around $8 \mathrm{~mL} / 2 \mathrm{~g}$ bentonite. This reduction in swell volume can be mainly attributed to the presence of iron due to its high concentration in the ARD (around 4,500 mg/L). This assumption can be demonstrated in Figure 3 and 4 in which the swell index of different $\mathrm{Fe}$ and As single metal concentrations (Figure 3) and the effect of Fe and As present in the ARD to the swell index (Figure 4) were evaluated.

From Figure 3, it can be seen that a Fe concentration higher than $100 \mathrm{mg} / \mathrm{L}$ negatively impacts the swell index by decreasing it. However, As does not affect the swell index even at concentrations higher than $100 \mathrm{mg} / \mathrm{L}$.

Swelling, in combination with the diffuse double layer (DDL), constitutes one of the most important reasons why GCLs provide the low levels of hydraulic conductivity ${ }^{7)}$ necessary to prevent the migration of toxic substances from rock containment facilities into groundwater. The reduction in swell index caused by metals was studied by Jo et al. ${ }^{15)}$. They indicate that the increase in metal concentration makes water move out of the mineral interlayer and then a reduction in swell volume occurs.
As swell index reduction was observed (from 32 to 8 $\mathrm{mL} / 2 \mathrm{~g}$ bentonite) due to high metal concentration in the ARD (Figure 2), an increase in hydraulic conductivity was expected in the GCL permeated with ARD. The 9month hydraulic conductivity tests, presented in the next section, Figure 5, showed that the hydraulic conductivity of GCL was one order of magnitude higher in the ARD permeation case than the water permeation case. Although the high concentration of iron in this experiment negatively impacts the performance of the GCL, it seems to have a crucial role in the As retention in the GCL.

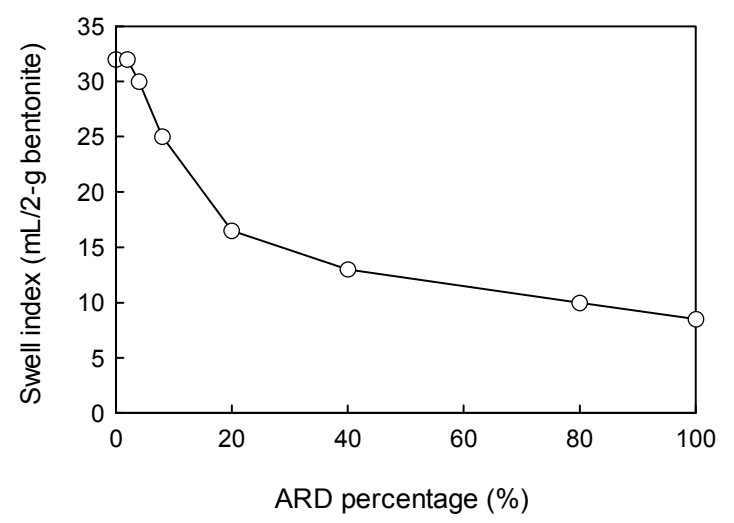

Figure 2. Swell index at different ARD percentage (data from Naka et al, 20112)

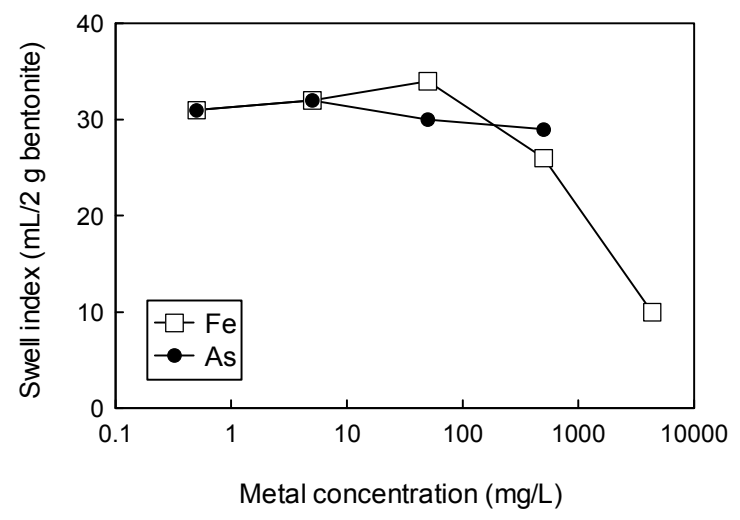

Figure 3. Swell index at different metal concentration

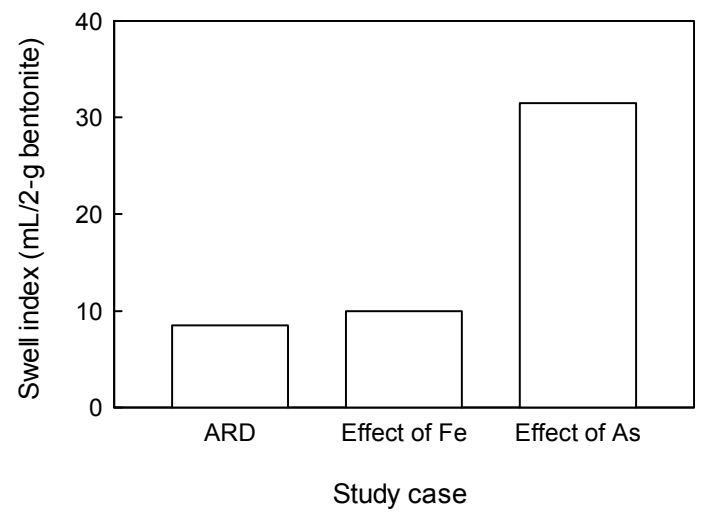

Figure 4. Swell index of ARD (100\%ARD), Fe effect on swelling (4330.2 mg/L), and As effect on swelling (49.1 mg/L) 


\section{(2) Hydraulic conductivity test}

Changes in hydraulic conductivity values $(k)$ versus pore volumes of flow (PVF) are illustrated in Figure 5. $\mathrm{PVF}$, which is a non-dimensional parameter, was calculated by dividing the cumulative amount of effluent collected during the test $\left(\mathrm{m}^{3}\right)$ by the volume of voids in the specimen $\left(\mathrm{m}^{3}\right)$.

The hydraulic conductivity of GCL permeated with distilled water was constant over time (correlated to PVF and vice versa), with an average value of $1.4 \times 10^{-11} \mathrm{~m} / \mathrm{s}$. The hydraulic conductivity of the ARD prehydrated and permeated with ARD gradually increased over time, until 150 PVF approximately. After this point, it stabilized, reaching an average permeability value of $5.0 \times 10^{-10} \mathrm{~m} / \mathrm{s}$. At approximately $300 \mathrm{PVF}$ it started decreasing again due to physical clogging, mainly attributed to iron precipitation observed in Figure 6 (brown-red color on the specimen).

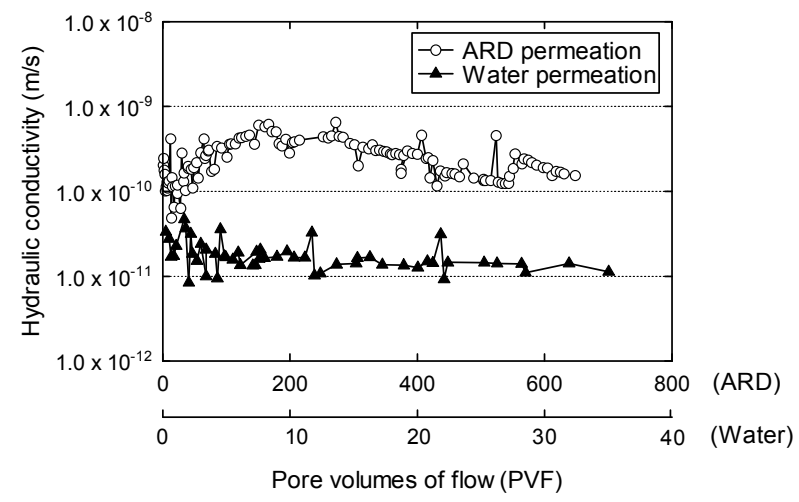

Figure 5. Hydraulic conductivity of GCL a) permeated with distilled water and b) prehydrated and permeated with ARD (data from Naka et al., 2011 ${ }^{12)}$ )

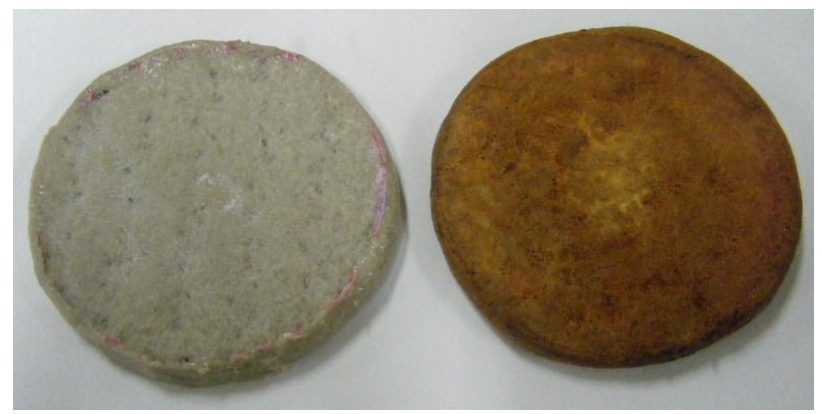

Figure 6. GCL after hydraulic conductivity test a) water permeation and b) ARD prehydration and permeation

One of the most important factors of bottom liner systems for rock containment facilities is to achieve a low permeability since they prevent waste leachates from having an adverse impact on soil and groundwater. The hydraulic conductivity differs according to the type of soil. The low hydraulic conductivity of GCLs, attributed to the swelling and water retention capacity of bentonites, make them suitable for barrier systems, according to the regulations established by different countries. The regulated hydraulic conductivity value in North America and Europe is $10^{-9} \mathrm{~m} / \mathrm{s}$. In Japan, the regulation permits a natural clay $\geq 5 \mathrm{~m}$ in thickness with hydraulic conductivity $\leq 10^{-7} \mathrm{~m} / \mathrm{s}$ to be utilized as a liner. Otherwise, one of the following liner systems is required: (1) two geomembranes (GMs) which sandwich a nonwoven fabric or other cushion material, (2) a GM underlain by an asphalt-concrete layer $\geq 0.05 \mathrm{~m}$ in thickness and having hydraulic conductivity $\leq 10^{-9} \mathrm{~m} / \mathrm{s}$, or (3) a GM underlain by a clay liner $\geq 0.5 \mathrm{~m}$ in thickness and having hydraulic conductivity $\leq 10^{-8} \mathrm{~m} / \mathrm{s}^{16}$.

Besides hydraulic conductivity, $\mathrm{pH}$, as well as EC, and metal release over time also constitute important factors to be considered. Effluent analysis of each case was conducted.

In the water permeated GCL case, the $\mathrm{pH}$ of the effluent was constant over time at approximately 10 (Figure 7). These high $\mathrm{pH}$ values can be attributed to the temporary alkalinity contribution of the cations released from the $\mathrm{GCL}(\mathrm{Ca}, \mathrm{Mg}, \mathrm{Na}$, and $\mathrm{K})$ and/or the adsorption of $\mathrm{H}^{+}$onto the GCL. From Figure 8, it can be seen that the EC changed over time. At 6 PVF, the EC was 619 $\mathrm{mS} / \mathrm{m}$ and after $35 \mathrm{PVF}$, it decreased to $140 \mathrm{mS} / \mathrm{m}$ (Figure 8).

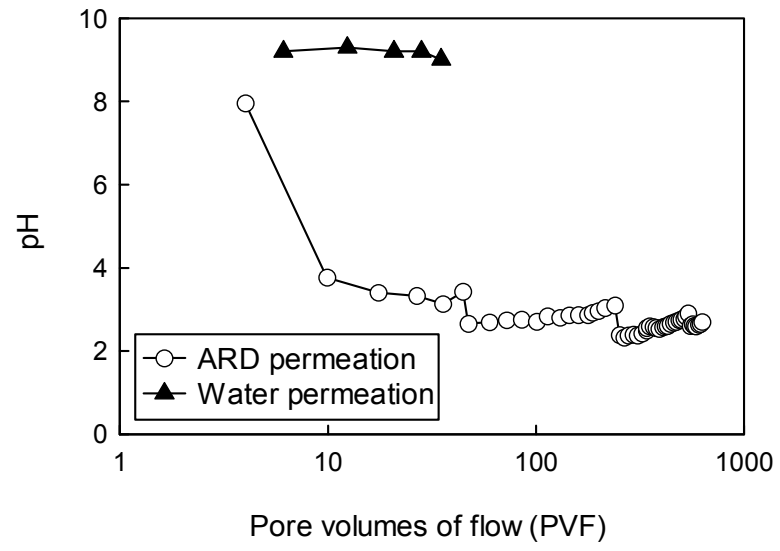

Figure 7. Change of $\mathrm{pH}$ over time for GCL permeated with ARD and water (data from Naka et al., 2011 ${ }^{12)}$ )

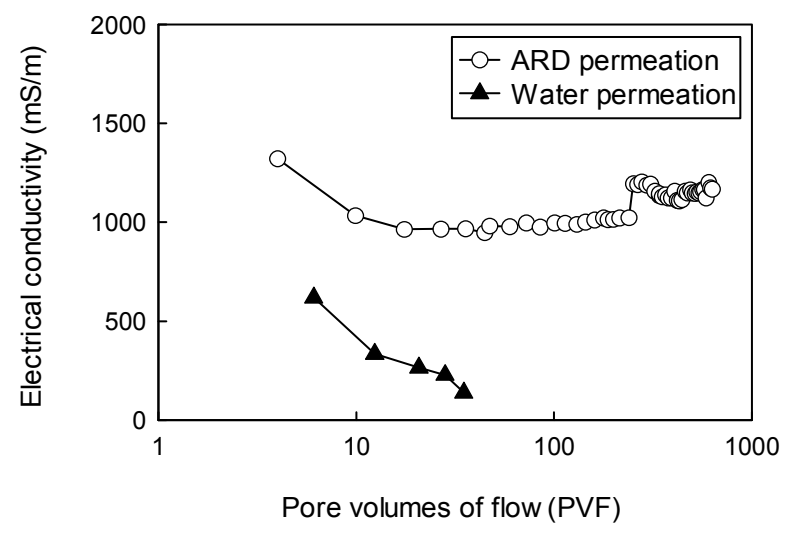

Figure 8. Change of EC over time for GCL permeated with ARD and water (data from Naka et al., 2011 ${ }^{12)}$ )

Effluent analysis in case of GCL prehydrated and permeated with ARD showed that after $4 \mathrm{PVF}$ the $\mathrm{pH}$ 
was 8 , but after 10 PVF it decreased to 3.8 and continued decreasing until $\mathrm{pH} 3$, which was equivalent to the $\mathrm{pH}$ of the initial solution (Figure 7). It indicates that the $\mathrm{pH}$ equilibrium was reached at around 50 PVF. EC equilibrium was also observed, with an average value of $1000 \mathrm{mS} / \mathrm{m}$ (Figure 8). Variation in EC values can be attributed to metal leaching and/or desorption.

In order to study the role of $\mathrm{Fe}$ in As retention, data presented from Figure 9 to 12 will be limited to these two metals. Information of the other metals, such as release and sorption are presented in the authors' previous publications $^{12), 13)}$.

Figure 9 illustrates the metal concentration ratio of $\mathrm{Fe}$ and As over time. The metal concentration was reported in terms of metal concentration ratio, which is the ratio between the outflow and the inflow.

$$
\text { Metal concentration ratio }=\frac{C}{C_{0}}
$$

where $C$ is the metal concentration in the outflow and $C_{0}$ is the metal concentration in the inflow.

At $210 \mathrm{PVF}$ for $\mathrm{Fe}$, an increase above the influent concentration values (ratio larger than 1) were observed, which may indicate a release of these species from GCL (desorption). The metal concentration ratio for As remained below the influent concentration value (ratio lower than 1), even after 600 PVF. This suggests that As was prevented from breaking through the GCL by sorption onto other metals present in the ARD (mainly $\mathrm{Fe}$ ) which will be discussed more in section 3. Evidence of it is the red/orange layer of iron hydroxide in the GCL (Figure 6), observed also by Lange et al. ${ }^{11)}$.

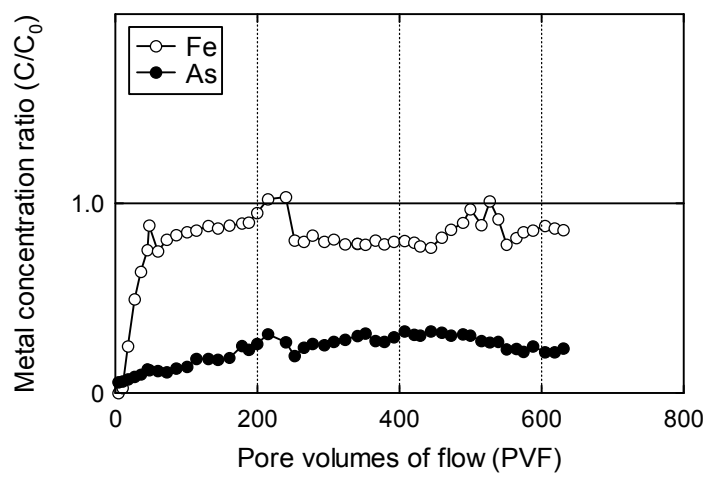

Figure 9. Heavy metal concentration ratio on GCL prehydrated and permeated with ARD (data from Naka et al., 2011 ${ }^{12)}$ )

\section{(3) Sorption test}

Figure 10 presents the isotherm for $\mathrm{Fe}$ and As sorption onto bentonite. It shows that Fe sorption onto bentonite is around $3 \mathrm{mmol} / \mathrm{g}$ bentonite. On the other hand, almost no adsorption was observed for As. Figure 11 shows $\mathrm{Fe}$ and $\mathrm{As}$ sorption at different ARD percentages (from 2 to $100 \%$ ARD) using $20 \mathrm{~g} / \mathrm{L}$ of bentonite. When the ARD percentage was lower than $10 \%$, all the Fe was sorbed onto bentonite. In case of As, at low ARD proportions, the As sorption was low. However, as the $\mathrm{Fe}$ concentration increased with the increase of the ARD proportion, more As was removed from the solution. However, Fe sorption was decreasing due to the saturation of bentonite. This suggests that Fe is retained in bentonite though ion exchange, whereas for As, an additional mechanism that involves Fe may occur. The partition coefficient, $K_{d}$, was calculated from the soil concentration $\left(C_{s}\right)$ and respective porewater concentration $\left(C_{a q}\right)$ at test termination, based on:

$$
K_{d}=\frac{C_{s}}{C_{a q}}
$$

For the artificial ARD, assuming that the equilibrium was reached between the bentonite and the porewater at the end of the test, the $K_{d}$ (batch) value for $\mathrm{Fe}$ and As at $100 \%$ ARD was $12 \mathrm{~mL} / \mathrm{g}$ and $135 \mathrm{~mL} / \mathrm{g}$, respectively. The partition coefficient was calculated for every ARD dilution or ARD percentage that was used in the experiments. These values are presented in Table 2 .

Figure 12 shows the sorption percentage of each metal using different amount of bentonite (from 4 to $80 \mathrm{~g}$ bentonite/L solution). In the case of $\mathrm{Fe}$ (initial concentration, $4330.2 \mathrm{mg} / \mathrm{L}$ ), $75 \%$ was sorbed by $80 \mathrm{~g} / \mathrm{L}$ of bentonite. For As, it was observed that the sorbed amount was constant, even at high adsorbent concentration, due to the presence of $\mathrm{Fe}$ in the solution. It suggests that As is immobilized on the precipitated iron oxides or iron hydroxide, $\mathrm{Fe}(\mathrm{OH})_{3}$, through a surface complexation reaction (Figure 13), and probably to other metals presents in ARD as well.

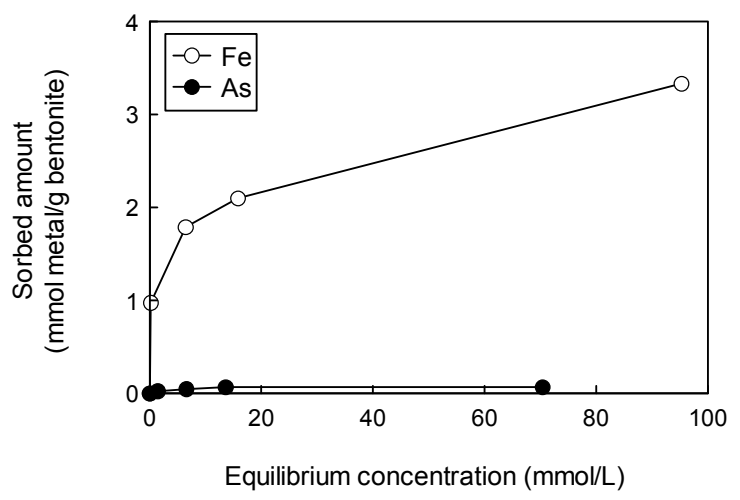

Figure 10. Fe and As sorption on bentonite at $20 \mathrm{~g}$ bentonite/L solution (excerpt from Naka et al. ${ }^{12), 13)}$ )

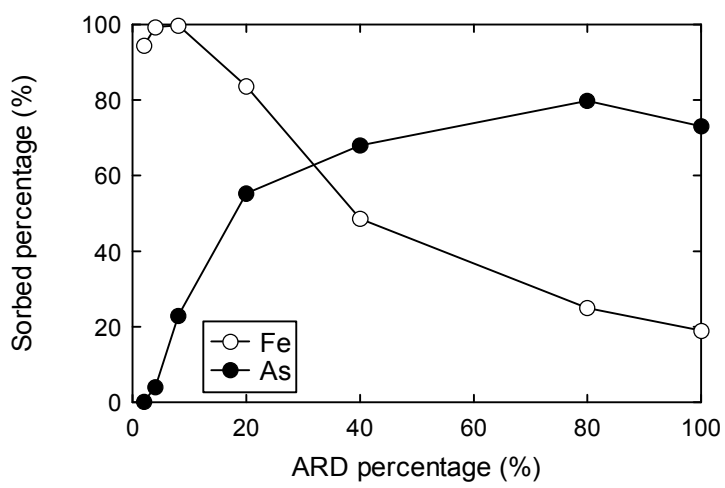

Figure 11. Fe and As sorption on bentonite at different ARD percentage (data from Naka et al., 2010 and 20112), 13) 
Table 2. Partition coefficient at different ARD percentage

\begin{tabular}{crc}
$\begin{array}{c}\text { ARD } \\
\text { percentage }\end{array}$ & $\begin{array}{c}K_{d} \text { for Fe } \\
(\mathrm{mL} / \mathrm{g})\end{array}$ & $\begin{array}{c}K_{d} \text { for As } \\
(\mathrm{mL} / \mathrm{g})\end{array}$ \\
\hline 2 & 838 & 0 \\
4 & 6,988 & 2 \\
8 & 21,864 & 15 \\
20 & 256 & 62 \\
40 & 47 & 107 \\
80 & 17 & 198 \\
100 & 12 & 135 \\
\hline
\end{tabular}

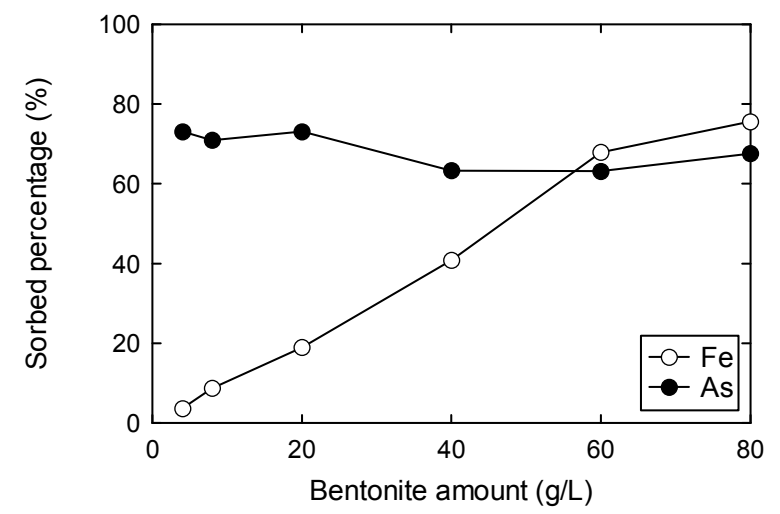

Figure 12. Fe and As sorption on bentonite at different sorbent amount (data from Naka et al., 2011 ${ }^{13)}$ )

The sorption reaction of As onto $\mathrm{Fe}$ is different depending on the specie. For di- and monovalent anions, the equation can defined as follows ${ }^{17)}$ :

(1) Iron hydroxide formation:

$\mathrm{Fe}^{2+}+1 / 4 \mathrm{O}_{2}+\mathrm{H}^{+} \rightarrow \mathrm{Fe}^{3+}+1 / 2 \mathrm{H}_{2} \mathrm{O}$

$\mathrm{Fe}^{3+}+3 \mathrm{OH}^{-} \rightarrow \mathrm{Fe}(\mathrm{OH})_{3}$

(2) Anion adsorption onto iron hydroxide:

$\equiv \mathrm{Fe}-\mathrm{wOH}+\mathrm{A}^{\mathrm{a}-}+\mathrm{H}^{+} \rightarrow \equiv \mathrm{Fe}-\mathrm{wA}^{(\mathrm{a}+1)-}+\mathrm{H}_{2} \mathrm{O}$

$\equiv \mathrm{Fe}-\mathrm{wOH}+\mathrm{A}^{\mathrm{a}-} \rightarrow \equiv \mathrm{Fe}-\mathrm{wOA}^{\mathrm{a}-}$

where $\equiv$ refers to adsorption sites and w to weak adsorption sites in the two-layer surface complexation model.

For arsenate or As(V), Dixit and Hering ${ }^{18)}$ have proposed the following equations with their respective intrinsic surface complexation constants:

$$
\begin{aligned}
\equiv & \mathrm{FeOH}+\mathrm{AsO}_{4}{ }^{3-}+3 \mathrm{H}^{+} \rightarrow \equiv \mathrm{FeH}_{2} \mathrm{AsO}_{4}+\mathrm{H}_{2} \mathrm{O} \\
& \left(\log \mathrm{K}^{\text {int }}=29.88\right) \\
\equiv & \mathrm{FeOH}+\mathrm{AsO}_{4}{ }^{3-}+2 \mathrm{H}^{+} \rightarrow \equiv \mathrm{FeH}_{2} \mathrm{AsO}_{4}{ }^{-}+\mathrm{H}_{2} \mathrm{O} \\
& \left(\log \mathrm{K}^{\mathrm{int}}=24.43\right) \\
\equiv & \mathrm{FeOH}+\mathrm{AsO}_{4}{ }^{3-}+\mathrm{H}^{+} \rightarrow \equiv \mathrm{FeH}_{2} \mathrm{AsO}_{4}{ }^{2-}+\mathrm{H}_{2} \mathrm{O} \\
& \left(\log \mathrm{K}^{\text {int }}=18.10\right)
\end{aligned}
$$

High values of the intrinsic surface complexation constants suggest that the reaction or interaction between
As and Fe is favored.

Figure 13 shows the possible pathways of As secondary sorption on bentonite, proposed by Davis et al. ${ }^{19)}$. This illustrates both monodentate and bidentate bonding using arsente complexes.

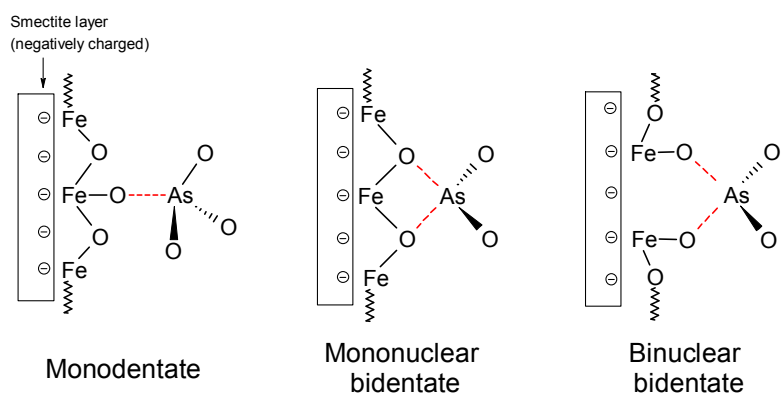

Figure 13. Possible pathways of As secondary sorption (sorption on $\mathrm{Fe}$ ) on bentonite ${ }^{19)}$

Figure 14 shows the As sorption $(1 \mathrm{mM})$ in the presence of a second metal of the same concentration (1 $\mathrm{mM})$. It suggests that for As immobilization onto bentonite, a secondary metal such as $\mathrm{Fe}$ plays an important role. In addition this graph shows that As has higher affinity towards Fe. At $1 \mathrm{mmol} / \mathrm{L}$ of $\mathrm{Fe}$ and 1 mmol of As, 70\% of As was sorbed. Besides, in presence of $\mathrm{Al} 50 \%$ of As was sorbed, in presence of $\mathrm{Cu}, 35 \%$, in presence of $\mathrm{Zn}, 60 \%$ and in presence of $\mathrm{Pb}, 55 \%$. This slightly higher affinity towards $\mathrm{Fe}$ and the high concentration of $\mathrm{Fe}$ in the ARD suggests that $\mathrm{Fe}$ is the main binding site for As present in the ARD solution and the responsible for its immobilization.

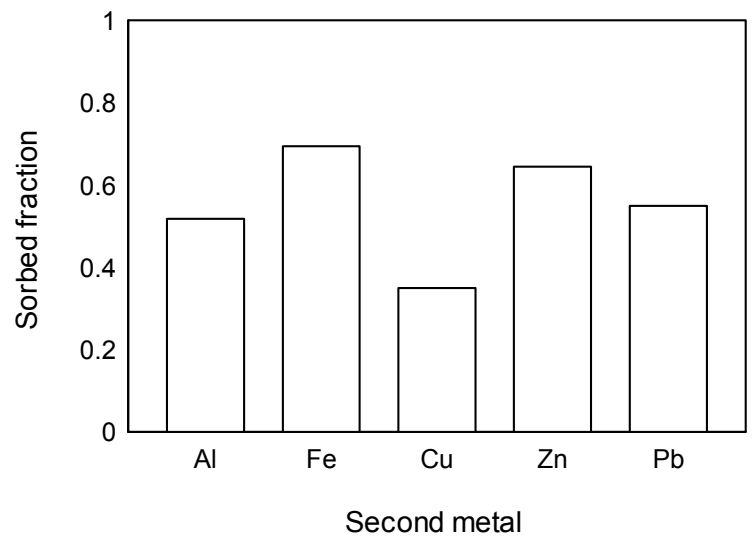

Figure 14. Sorption of As in presence of a second metal (bimetal sorption test)

\section{CONCLUSIONS}

The swell index of distilled water adjusted to $\mathrm{pH} 3$ using $\mathrm{H}_{2} \mathrm{SO}_{4}$ was $32 \mathrm{~mL} / 2 \mathrm{~g}$ bentonite, while the swell volume of bentonite in presence of ARD was $8 \mathrm{~mL} / 2 \mathrm{~g}$ bentonite. This value is highly influenced by the amount of Fe in the ARD.

The hydraulic conductivity for distilled water 
remained constant at around $1.4 \times 10^{-11} \mathrm{~m} / \mathrm{s}$. The hydraulic conductivity of the GCL prehydrated and permeated with an artificial ARD solution gradually increased, but between 150 and $300 \mathrm{PVF}$ it became stable and reached a $k$ value of $5 \times 10^{-10} \mathrm{~m} / \mathrm{s}$. After $300 \mathrm{PVF}, k$ started decreasing due to physical clogging caused by metal precipitation.

The sorption test with single metal solution showed that bentonite has affinity for Fe, but not for As. Different ARD dilutions showed that the increase of $\mathrm{Fe}$ concentration impacts on the As sorption.

Considering that GCLs do not retain As, an additional $\mathrm{Fe}$ layer should be placed in the bottom liner system in order to immobilize it. However, if the ARD contains high $\mathrm{Fe}$ concentration, this additional layer is not necessary as the $\mathrm{Fe}$ in solution will prevent the As migration.

Although an increase of an order of magnitude was observed after ARD permeation, the hydraulic conductivity remained low enough to meet the standard requirement. In addition, a relatively high metal attenuation capacity even under extreme conditions was observed which make GCLs a solution for ARD mitigation.

Other factors such as mineral-metal interactions, metal ion transport through minerals, $\mathrm{pH}$ effects, desorption processes, etc. must be thoroughly studied prior to field applications to assure long-term performance. In other words, additional systematic studies about the chemical compatibility of bentonite are required before applying GCLs to bottom liners in rock waste containment facilities, especially because the metal concentration and composition in ARD, which strongly influence GCL performance, differ by location.

\section{ACKNOWLEDGEMENT}

The first author's postgraduate studies are financially supported by the Nikkei Scholarship granted by The Nippon Foundation (Nippon Zaidan). The authors express deep gratitude to Dr. Hermelinda Plata and Mr. Juan Carlos Bobea (Kyoto University) for their helpful discussions and constructive comments.

\section{REFERENCES}

1) Katsumi, T., Inui, T., Mogami, H., Dejima, A., and Kamon, M.: GCLs against acid drainage from excavated rocks discharged through construction works, 9ICG 2010 Brazil - Proceedings of the 9th International Conference on Geosynthetics, Guaruja, Brazil, pp. 967-970, 2010.

2) Katsumi, T., Inui, T., and Kamon, M.: Wastes and byproducts used in geotechnical applications in Japan, GeoEnvironmental Engineering 2008 - Proceedings of the 8th Japan-Korea-France Joint Seminar on Geoenvironmental Engineering, Kyoto, Japan, pp. 275-282, 2008.

3) Katsumi, T., Inui, T., and Kamon, M.: Sustainable geotechnics for reuse of by-products, Environmental Geotechnics for Sustainable Development - Proceedings of the 6th International Congress on Environmental Geotechnics, New Delhi, India, pp. 302-317, 2010.

4) Ohta, T., Hattori, S., and Kikuchi, Y.: Water-Rock Interaction and Heavy Metal Drainage at Rock Muck Disposal Sites, IAEG Congress 2010 - Proceedings of the 11th Congress of the International Association for Engineering Geology and the Environment, Auckland, New Zealand, pp. 547-556, 2010.

5) Ohta, T., Enomoto, H., and Tokunaga, T.: Evaluation and prediction of pollution caused by acid water exuded from mud sediment in urban ground, IAEG Congress 2006 Proceedings of the 10th Congress of the International Association for Engineering Geology and the Environment, Nottingham, United Kingdom, pp. 1-9, 2006.

6) Lottermoser, B. G.: Mine wastes: characterization, treatment and environmental impacts, 2nd ed., Berlin, Springer, pp. 304, 2007.

7) Katsumi, T.: Hydraulic conductivity of geosynthetic clay liners, Geosynthetic Clay Liners for Waste Containment Facilities, A. Bouazza and J. Bowders, London, CRC Press/Balkema, pp. 55-83, 2010.

8) Lange, K., Rowe, R. K., and Jamieson, H.: The potential role of geosynthetic clay liners in mine water treatment systems, Geotextiles and Geomembranes, Vol. 28, No. 2, pp. 199-205, 2010.

9) Shackelford, C. D., Sevick, G. W., and Eykholt, G. R.: Hydraulic conductivity of geosynthetic clay liners to tailings impoundment solutions, Geotextiles and Geomembranes, Vol. 28, No. 2, pp. 149-162, 2010.

10) Abollino, O., Aceto, M., Malandrino, M., Sarzanini, C., and Mentasti, E.: Adsorption of heavy metals on Namontmorillonite. Effect of $\mathrm{pH}$ and organic substances, Water Research, Vol. 37, No. 7, pp. 1619-1627, 2003.

11) Lange, K., Rowe, R. K., Jamieson, H., Flemming, R. L., and Lanzirotti, A.: Characterization of geosynthetic clay liner bentonite using micro-analytical methods, Applied Geochemistry, Vol. 25, pp. 1056-1069, 2010.

12) Naka, A., Katsumi, T., Inui, T., Takai, A., and Ohta, T.: Long-term performance of geosynthetic clay liners used in acid rock drainage mitigation, Geosynthetics Engineering Journal, Japan Chapter of International Geosynthetics Society, Vol. 26, pp. 137-144, 2011.

13) Naka, A., Li, Z., Inui, T., Katsumi, T., and Mogami, H.: Heavy metals retention in geosynthetic clay liners and its potential role in acid rock drainage treatment, Geosynthetics Engineering Journal, Japan Chapter of International Geosynthetics Society, Vol. 25, pp. 233-240, 2010.

14) Wibkirchen, C., Dold, B., Friese, K., and Glaber, W.: Hydrogeochemistry and sediment mineralogy of Lake Yanamate - an extremely acidic lake caused by discharge of acid mine drainage from the $\mathrm{Pb}-\mathrm{Zn}-(\mathrm{Cu})$ deposit, Cerro de Pasco (Peru), Securing the Future, pp. 1013-1022, 2005.

15) Jo, H. Y., Katsumi, T., Benson, C. H., and Edil, T. B.: Hydraulic conductivity and swelling of nonprehydrated 
GCLs permeated with single-species salt solutions, Journal of Geotechnical and Geoenvironmental Engineering, Vol. 127, No. 7, pp. 557-567, 2001.

16) Kamon, M., and Katsumi, T.: Clay liners for waste landfill, Clay Science for Engineering, K. Adachi and M. Fukue eds., Balkema, Rotterdam, pp. 29-45, 2001.

17) Appelo, C. A. J., and Postma, D.: Geochemistry, groundwater and pollution, 2nd ed., CRC Press Taylor \& Francis Group, pp. 649, 2009.

18) Dixit, S., and Hering, J. G.: Comparison of arsenic (V) and arsenic (III) sorption onto iron oxide minerals: implications for arsenic mobility, Environmental Science \& Technology, Vol. 37, No. 18, pp. 4182-4189, 2003.

19) Davis, J. A., James, R. O., and Leckie, J. O.: Surface ionization and complexation at the oxide/water interface: I. Computation of electrical double layer properties in simple electrolytes, Journal of Colloid and Interface Science, Vol. 63, No. 3, pp. 480-499, 1978.

\title{
酸性廃水に対するジオシンセティッククレイライナーの性能評価 : 砒素の固定 化における鉄の役割
}

\author{
ナカ アンヘリカ・勝見 武・太田岳洋・フローレス ジャンカルロ・ \\ 乾 徹・高井敦史
}

ジオシンセティッククレイライナー(GCLs)には重金属の固化効果が期待できるため, これま で廃棄物処分場の底部遮水ライナーや, 酸性廃水(ARD)を生じる可能性のある掘削ずりの封じ 込め等に用いられてきた。しかしARD中の有害物質の一つである砒素は陰イオンとして存在す ることから，陽イオンとの親和性があるGCLs中のベントナイトに吸着されにくい。本研究では， 既往研究で著者らが実施したベントナイトの膨潤試験, 吸着試験, GCLsの透水試験の結果をと りまとめ, 鉄の存在が砒素のベントナイトへの固化効果, GCLsの遮水性能に与える影響につい て考察を行った。その結果約 $4,500 \mathrm{mg} / \mathrm{L} の$ 鉄イオン等, 高濃度で金属イオンが存在する場合に はベントナイトの膨潤量が低下しGCLsの透水係数が上昇することが明らかとなった。GCLsの 透水係数は条件に関わらず透水試験実施期間を通して低い透水係数を示したものの，透水溶液 にARDを用いた場合 $5.0 \times 10^{-10} \mathrm{~m} / \mathrm{s}$ であり，水を用いた場合の $1.4 \times 10^{-11} \mathrm{~m} / \mathrm{s}$ と比較して 1 オーダ一高 い值を示した。単一金属イオン溶液を用いた吸着試験結果から, 濃度に関わらず砒素は吸着さ れないものの鉄は濃度の上昇に伴い吸着量が増加することがわかった。異なる希勫濃度のARD を用いた場合には，ARD濃度が高く金属イオン濃度が高くなるほど砒素の吸着量も増加するこ とがわかった。これらの結果からGCLsそのものの砒素吸着能は低いものの鉄の存在下では砒素 が吸着されうると言え, 底部遮水層として砒素の吸着を見込む場合においては鉄を含有する層 を複合的に設置する必要があると考えられる。しかしARD中に鉄が存在する場合にはそれが砒 素の固化に寄与するため不要であると考えられる.

KEYWORDS: ベントナイト，重金属，透水試験，透水係数，膨潤試験，吸着試験 